\title{
EKSISTENSI KEDAULATAN RAKYAT DAN IMPLEMENTASI PARLIAMENTARY THRESHOLD DALAM SISTEM PEMILIHAN UMUM DI INDONESIA
}

\author{
Fahri Bachmid \\ Dosen Fakultas Hukum, Universitas Muslim Indonesia, Makassar \\ Email Korespondensi:fahri.bachmid@umi.ac.id
}

\begin{abstract}
Abstrak. Penelitian ini bertujuan untuk menguraikan lebih lanjut tentang pemberlakuan parliamentary threshold dalam sistem Pemilu, serta pertentangannya dengan konsep kedaulatan rakyat. pendekatan normatif, yang dimana bukan hanya mengkaji hukum dalam arti peraturan perundang-undangan semata, akan tetapi meliputi aspek yang lebih luas, yaitu sesuatu yang dapat ditelusuri melalui bahan kepustakaan. Teknis analisis yang digunakan dalam penelitian ini adalah metode analisis hermeneutik dan interpretasi. Hasil penelitian menunjukkan bahwa pemberlakuan parliamentary threshold dalam sistem Pemilu di Indonesia bertentangan dengan konsep kedaulatan rakyat. Adapun penerapan sistem khususnya pada Pemilu 2024, patut mempertimbangkan sistem Campuran sebagai alternatif dari sistem Representasi Proporsional yang selama ini diterapkan pada Pemilu di Indonesia. Selanjutnya, dibutuhkan formulasi khusus dimana Partai Politik Peserta Pemilu yang dinyatakan tidak memenuhi ambang batas dapat menempuh jalur koalisi untuk mencapai ambang batas, bahkan sampai pada pilihan untuk meniadakan parliamentary threshold (ambang batas perolehan suara 0\%). Hal ini akan menjadi jalan tengah atas kebutuhan pencapaian proporsionalitas sistem Pemilu, sebagai bentuk akomodasi suara pemilih serta kepastian hukum atas kedaulatan rakyat, serta kebutuhan menciptakan sistem Presidensialisme yang semakin efektif di masa yang akan datang.
\end{abstract}

Kata Kunci:

Kedaulatan Rakyat; Parliamentary Threshold; Partai Politik; Sistem Pemilu.

artikel dengan akses terbuka dibawah lisensi CC BY -4.0

\section{PENDAHULUAN}

Kedaulatan rakyat menggambarkan suatu sistem dalam sebuah negara yang menghendaki kekuasaan tertinggi dipegang oleh rakyat. ${ }^{1}$ Kedaulatan rakyat juga menggambarkan pemenuhan kehendak umum yang tidak hanya berkaitan dengan hal-hal penyelenggaraan kekuasaan pemerintah dan peradilan, tetapi juga kekuasaan dalam pembentukan peraturan, ${ }^{2}$ sebagaimana berdasarkan Pasal 1 ayat (2) Undang-

${ }^{1}$ Mohamad Faisal Ridho. (2017). Kedaulatan Rakyat sebagai Perwujudan Demokrasi Indonesia. 'Adalah: Jurnal Ilmu Hukum, Universitas Islam Negeri Syarif Hidayatullah Jakarta, 8(1), hlm. 79.

${ }^{2}$ Setyo Nugroho. (2013). Demokrasi dan Tata Pemerintahan dalam Konsep Desa dan Kelurahan. Jurnal Cita Hukum, Universitas Islam Negeri Syarif Hidayatullah Jakarta, 1(2), hlm. 250. 
Undang Dasar Negara Republik Indonesia Tahun 1945 (selanjutnya disebut UUD NRI Tahun 1945), yang mengatur bahwa "Kedaulatan berada di tangan rakyat dan dilaksanakan menurut Undang-Undang Dasar".

Selanjutnya, konsep kedaulatan rakyat diterjemahkan melalui sistem Pemilihan Umum (Pemilu), dimana menghendaki suatu pejabat publik sebagai representatif atau perwakilan rakyat. ${ }^{3}$ Pemilu menjadi sarana bagi rakyat dalam menegosiasikan dan mengagregasikan aspirasi dan kepentingannya. ${ }^{4}$ Pemilu bukan sekedar partisipasi tetapi implementasi prinsip kedaulatan rakyat. ${ }^{5}$ Dilain sisi, kedaulatan rakyat merupakan sumber utama dari kekuasaan yang dimiliki negara, maka regulasi tentang Pemilu hendaklah memiliki karakter hukum yang bermartabat dan demokratis. ${ }^{6}$ Berdasarkan Pasal 1 angka 1 Undang-Undang Republik Indonesia Nomor 7 Tahun 2017 tentang Pemilihan Umum (selanjutnya disebut UU No. 7 Tahun 2017), menjelaskan bahwa:

\section{"Pemilihan Umum yang selanjutnya disebut Pemilu adalah sarana kedaulatan rakyat untuk memilih anggota Dewan Perwakilan Rakyat, anggota Dewan Perwakilan Daerah, Presiden dan Wakil Presiden, dan untuk memilih anggota Dewan Perwakilan Rakyat Daerah, yang dilaksanakan secara langsung, umum, bebas, rahasia, jujur, dan adil dalam Negara Kesatuan Republik Indonesia berdasarkan Pancasila dan Undang-Undang Dasar Negara Republik Indonesia Tahun 1945."}

Dari ketentuan di atas, Pemilu dapat dimaknai sebagai salah satu sarana media agar mewujudkan relasi yang demokratis antara rakyat dengan negara (pemerintahan). ${ }^{7}$ Salah satu instrumen negara terkait perwakilan rakyat ialah lingkup kekuasaan legislatif, dimana bertugas untuk membentuk sebuah regulasi yang bermanfaat bagi hajat hidup seluruh rakyat Indonesia. ${ }^{8}$

Sejak zaman kemerdekaan, Pemilu telah diselenggarakan dan terus berusaha menemukan sistem yang tepat untuk diterapkan di Indonesia. Adapun pengelompokan proses Pemilu, ${ }^{9}$ antara lain:

1. Zaman Demokrasi Parlementer (1945-1959), dengan sistem proporsional serta menggunakan metode kuota, dimana Pemilu Tahun 1955 (berdasarkan UU No. 7 Tahun 1953) diikuti oleh 70 Kelompok (36 Partai Politik dan 34 Organisasi) Partai Politik dan 48 Perorangan. Terdapat 27 (tujuh) Kelompok dan 1 (satu) Perorangan

\footnotetext{
${ }^{3}$ Syofyan Hadi. (2013). Fungsi Representative Dewan Perwakilan Rakyat Daerah dalam Sistem Otonomi. DIH: Jurnal Ilmu Hukum, Universitas 17 Agustus 1945 Surabaya, 9(17), hlm. 48.

${ }^{4}$ Luthfi Widagdo Eddyono. (2017). Wacana Desentralisasi Partai Politik: Kajian Original Intent dan Pemaknaan Sistematik UUD 1945. Jurnal Konstitusi, Mahkamah Konstitusi RI, 14(1), hlm. 82.

${ }^{5}$ Latipah Nasution. (2017). Pemilu dan Kedaulatan Rakyat. 'Adalah: Jurnal Ilmu Hukum, Universitas Islam Negeri Syarif Hidayatullah Jakarta, 1(9), hlm. 84.

${ }^{6}$ S. Sodikin. (2014). Kedaulatan Rakyat dan Pemilihan Kepala Daerah dalam Konteks Undang-Undang Dasar Negara Republik Indonesia Tahun 1945. Jurnal Cita Hukum, Universitas Islam Negeri Syarif Hidayatullah Jakarta, 2(1), hlm. 108.

${ }^{7}$ Sri Hastuti Puspitasari. (2004). Pemilu dan Demokrasi Telaah terhadap Prasyarat Normatif Pemilu. Jurnal Hukum Ius Quia Iustum, Universitas Islam Indonesia Yogyakarta, 11(25), hlm. 136.

${ }^{8}$ Khairul Fahmi. (2010). Prinsip Kedaulatan Rakyat dalam Penentuan Sistem Pemilihan Umum Anggota Legislatif. Jurnal Konstitusi, Mahkamah Konstitusi RI, 7(3), hlm. 148.

${ }^{9}$ Abd. Rahman Mawazi. (2017). Dinamika Partai Politik dalam Sistem Presidensil di Indonesia. In Right: Jurnal Agama dan Hak Azazi Manusia, Universitas Islam Negeri Sunan Kalijaga Yogyakarta, 6(2), hlm. 144.
} 
terpilih di instansi DPR.

2. Zaman Demokrasi Terpimpin (1959-1965), terdiri dari 10 Partai Politik dan tidak menyelenggarakan Pemilu.

3. Zaman Demokrasi Pancasila (1965-1998), dengan sistem distrik serta menggunakan metode kuota hare ${ }^{10}$, dimana:

a. Pemilu Tahun 1971 (berdasarkan UU No. 15 Tahun 1969 dan PP No. 1 Tahun 1970) diikuti oleh 9 (sembilan) Partai Politik dan 1 (satu) golongan. Terdapat 7 (tujuh) Partai Politik dan 1 (satu) golongan terpilih di instansi DPR; dan

b. Pemilu Tahun 1977 (berdasarkan UU No. 4 Tahun 1975 dan PP No. 1 Tahun 1976), Pemilu Tahun 1982 (berdasarkan UU No. 2 Tahun 1980 dan PP No. 41 Tahun 1980), Pemilu Tahun 1987 (berdasarkan UU No. 1 Tahun 1985 dan PP No. 43 Tahun 1985), Pemilu Tahun 1992 (berdasarkan UU No. 1 Tahun 1985 dan PP No. 37 Tahun 1990), dan Pemilu Tahun 1997 (berdasarkan UU No. 1 Tahun 1985 dan PP No. 74 Tahun 1996) terjadi pengelompokan sehingga terdapat 2 Partai Politik dan 1 (satu) golongan:

1) Partai Demokrasi Indonesia (PDI);

2) Partai Persatuan Pembangunan (PPP); dan

3) Golongan Karya (Golkar).

4. Zaman Reformasi (1998-Sekarang), dengan sistem representasi proporsional:

a. Menggunakan metode kuota hare, dimana:

1) Pemilu Tahun 1999 (berdasarkan UU No. 3 Tahun 1999) diikuti oleh 48 Partai Politik. Terdapat 20 Partai Politik terpilih di instansi DPR; dan

2) Pemilu Tahun 2004 (berdasarkan UU No. 12 Tahun 2003) diikuti oleh 24 Partai Politik. Terdapat 16 Partai Politik terpilih di instansi DPR.

b. Memberlakukan parliamentary threshold serta menggunakan metode kuota hare, dimana:

1) Pemilu Tahun 2009 (berdasarkan UU No. 10 Tahun 2008) diikuti oleh 38 Partai Politik. Terdapat 9 (sembilan) Partai Politik terpilih di instansi DPR; dan

2) Pemilu Tahun 2014 (berdasarkan UU No. 8 Tahun 2012) diikuti oleh 12 Partai Politik. Terdapat 10 Partai Politik terpilih di instansi DPR.

c. Memberlakukan parliamentary threshold serta menggunakan metode divisor sainte lague ${ }^{11}$, dimana Pemilu Tahun 2019 (berdasarkan UU No. 7 Tahun 2017) diikuti oleh 16 Partai Politik. Terdapat 9 (sembilan) Partai Politik terpilih di instansi DPR.

\footnotetext{
${ }^{10}$ Kuota hare/bilangan pembagi pemilih (BPP) adalah metode konversi perolehan suara menjadi kursi perwakilan Partai Politik, dengan cara membagi keseluruhan suara sah semua Partai Politik peserta Pemilu dengan total/kuota kursi pada dapil tersebut. Metode kuota hare umumnya disertai dengan pembagian sisa kursi kepada Partai Politik peserta Pemilu berdasarkan urutan sisa suara terbanyak pada dapil tersebut. Lihat Ramlan Surbakti, Didik Supriyanto, \& Topo Santoso. (2011). Memaksimalkan Derajat Keterwakilan Partai Politik dan Meningkatkan Akuntabilitas Calon Terpilih. Jakarta: Kemitraan bagi Pembaruan Tata Pemerintahan, hlm. 8-9.

${ }^{11}$ Divisor sainte lague merupakan metode konversi perolehan suara menjadi kursi perwakilan Partai Politik, dengan cara membagi total suara setiap Partai Politik peserta Pemilu dengan bilangan ganjil $(1,3$, 5,7 , dan seterusnya) lalu diurutkan berdasarkan jumlah kursi pada dapil tersebut (divide by sequential odd numbers). Ibid., hlm. 11.
} 
Hadirnya parliamentary threshold (PT) dalam sistem Pemilu merupakan bentuk penyederhanaan sistem multipartai yang berlaku di Indonesia, ${ }^{12}$ sebagaimana berdasarkan Pasal 414 ayat (1) UU No. 7 Tahun 2017, mengatur bahwa:

"Partai Politik peserta Pemilu harus memenuhi ambang batas perolehan suara paling sedikit 4\% (empatpersen) dari jumlah suara sah secara nasional untuk diikutkan dalam penentuan perolehan kursi anggota DPR."

Akan tetapi dari ketentuan di atas, maka akan menghilangkan kesempatan seorang calon legislator yang memperoleh kursi anggota DPR pada dapilnya, karena Partai Politik pengusung calon tersebut tidak memenuhi PT. ${ }^{13}$ Ketentuan di atas juga akan berdampak pada hilangnya suara pemilih, dimana dapat diartikan sebagai bentuk hilangnya aspirasi rakyat. Hal itu bertentangan dengan jaminan hak asasi manusia, dan berujung pada pengebirian konsep kedaulatan rakyat. ${ }^{14}$

Berdasarkan uraian tersebut di atas, maka penelitian ini bertujuan untuk menguraikan lebih lanjut tentang pemberlakuan PT dalam sistem Pemilu, serta pertentangannya dengan konsep kedaulatan rakyat. Adapun manfaat dari penelitian tersebut adalah untuk memberikan pemahaman kepada para anggota DPR dalam membuat regulasi tentang Pemilu Tahun 2024 yang dimana harus mengakomodasi suara pemilih, dan sebagai bentuk kepastian hukum atas kedaulatan rakyat.

\section{METODE}

Penelitian ini menggunakan pendekatan normatif, yang dimana bukan hanya mengkaji hukum dalam arti peraturan perundang-undangan semata, akan tetapi meliputi aspek yang lebih luas, yaitu sesuatu yang dapat ditelusuri melalui bahan kepustakaan. ${ }^{15}$ Teknis analisis yang digunakan dalam penelitian ini adalah metode analisis hermeneutik dan interpretasi. Analisis hermeneutik digunakan untuk memahami teks sebagai serangkaian tanda yang di tata dengan cara tertentu oleh penulis untuk menyampaikan makna tertentu, ${ }^{16}$ sedangkan Analisis interpretasi digunakan untuk melakukan penafsiran dan mengungkap esensi ontologis, epistemologis, dan aksiologis ${ }^{17}$ yang terkait dengan tujuan penelitian ini.

\footnotetext{
${ }^{12}$ Jerry Indrawan \& M. Prakoso Aji. (2019). Penyederhanaan Partai Politik Melalui Parliamentary Threshold: Pelanggaran Sistematis terhadap Kedaulatan Rakyat. Jurnal Penelitian Politik, Pusat Penelitian Politik, Lembaga Ilmu Pengetahuan Indonesia (LIPI), 16(2), hlm. 159.

${ }^{13}$ Sunny Ummul Firdaus. (2011). Relevansi Parliamentary Threshold terhadap Pelaksanaan Pemilu yang Demokratis. Jurnal Konstitusi, Mahkamah Konstitusi RI, 8(2), hlm. 109.

${ }^{14}$ Abdul Rokhim. (2011). Pemilihan Umum dengan Model "Parliamentary Threshold" Menuju Pemerintahan yang Demokratis di Indonesia. DIH: Jurnal Ilmu Hukum, Universitas 17 Agustus 1945 Surabaya, 7(14), hlm. 90.

${ }^{15}$ Nurul Qamar \& Farah Syah Rezah. (2020). Metode Penelitian Hukum: Doktrinal dan Non-Doktrinal. Makassar: CV. Social Politic Genius (SIGn), hlm. 47.

${ }^{16}$ Jorge J. E. Gracia. (1990). Texts and Their Interpretation. The Review of Metaphysics, Philosophy of Education Society, Inc., 43(3), hlm. 496.

${ }^{17}$ H. Hastangka, Armaidy Armawi, \& Kaelan Kaelan. (2018). Analisis Putusan Mahkamah Konstitusi Nomor 100/PUU-XI/2013 tentang Pembatalan Frasa 4 Pilar Kehidupan Berbangsa dan Bernegara. Mimbar Hukum, Universitas Gadjah Mada, 30(2), hlm. 232.
} 


\section{HASIL DAN PEMBAHASAN}

\section{A. Sistem Pemilu}

Sistem Pemilu merupakan satu di antara beberapa unsur dalam institusi politik dan memiliki pengaruh yang sangat penting, khususnya terkait isu-isu tata pemerintahan yang lebih luas. ${ }^{18}$ Sistem Pemilu dibentuk guna memahami situasi perpolitikan sehingga dapat mengakomodasi perubahan-perubahan sikap dan perilaku elektoral masyarakat di masa depan. ${ }^{19}$ Selanjutnya, sistem Pemilu harus dijalankan secara dialektik, dimana terdapat pola hubungan antara rakyat dengan negara (pemerintahan), agar memberikan sumbangsih bagi perkembangan demokrasi. ${ }^{20}$ Dilain sisi, sistem Pemilu juga tidak sekedar dimaknai sebagai proses demokrasi secara sederhana, sebagaimana yang dikemukakan Joseph A. Schumpeter, bahwa: ${ }^{21}$

"Metode demokratis merupakan penataan kelembagaan, dimana individu berjuang secara kompetitif untuk meraih kekuasaan, sehingga sampai pada posisi pengambilan keputusan politik."

Adapun pandangan komprehensif yang dikemukakan oleh David Held, bahwa: ${ }^{22}$

"Otonomi demokrasi (democratic autonomy) ialah menempatkan kebebasan dan kesetaraan kepada warga negara dalam menentukan kehidupannya, selama berdasarkan atas hak dan kewajiban yang sama. Otonomi demokrasi pada prinsipnya membutuhkan akuntabilitas negara dan kontrol masyarakat."

Selanjutnya, Irfan Mawardi mengemukakan bahwa: ${ }^{23}$

"Konsep otonomi demokrasi menghendaki adanya hak-hak lain selain hak memilih, dimana para wakil yang memberi kesempatan kepada rakyat untuk berpartisipasi, menemukan, dan mengemukakan preferensi serta mengawasi proses dan agenda politik. Adanya partisipasi rakyat dalam memberikan preferensi merupakan beberapa titik point sebagai syarat meningkatkan kualitas hubungan antara rakyat dengan negara (pemerintahan)."

\footnotetext{
${ }^{18}$ Ellya Rosana. (2012). Partai Politik dan Pembangunan Politik. Jurnal Tapis: Jurnal Teropong Aspirasi Politik Islam, Universitas Islam Negeri Raden Intan Lampung, 8(1), hlm. 146.

${ }^{19}$ Agus Riwanto. (2014). Inkompatibilitas Asas Pengaturan Sistem Pemilu dengan Sistem Pemerintahan Presidensial di Indonesia. Jurnal Hukum Ius Quia Iustum, Universitas Islam Indonesia Yogyakarta, 21(4), hlm. 522. doi: https://doi.org/10.20885/iustum.vol21.iss4.art1

${ }^{20}$ Dhani Kurniawan. (2016). Demokrasi Indonesia dalam Lintasan Sejarah yang Nyata dan yang Seharusnya. Mozaik, Universitas Negeri Yogyakarta, 8(1), hlm. 96.

${ }^{21}$ Joseph A. Schumpeter. (1947). Capitalism, Socialism, and Democracy. New York: Harper \& Brothers, hlm. 260.

${ }^{22}$ David Held. (1987). Models of Democracy. Cambridge: Polity Press, hlm. 271.

${ }^{23}$ Irvan Mawardi. (2014). Dinamika Sengketa Hukum Administrasi di Pemilukada: Mewujudkan Electoral Justice dalam Kerangka Negara Hukum Demokratis. Yogyakarta: Rangkang Education, hlm. 59.
} 
Akan tetapi Robert Dahl mengingatkan bahwa: ${ }^{24}$

"Kualitas hubungan yang demokratis dipengaruhi oleh respon negara terhadap partisipasi dan preferensi dari rakyat. Responsifitas yang setara secara politis merupakan sifat-sifat dasar demokratis."

Berdasarkan uraian para pakar di atas, dapat dipahami bahwa dalam proses demokrasi mengandung prinsip-prinsip kedaulatan rakyat, antara lain yaitu: ${ }^{25}$

1. kebebasan;

2. kesamaan/kesetaraan;

3. suara mayoritas; dan

4. pertanggungjawaban.

Sistem Pemilu pada tingkatan paling dasar mengatur tata cara perolehan kursi berdasarkan perolehan suara Partai Politik peserta Pemilu. Adapun kategori dari sistem Pemilu, antara lain yaitu: ${ }^{26}$

1. Sistem Pluralitas/Mayoritas/Distrik:

a. Pertama Melewati Garis Finis/First Past the Post (FPTP);

b. Suara Blok/Block Vote (BV);

c. Suara Blok Partai/Party Block Vote (PBV);

d. Suara Alternatif/Alternative Vote (AV); serta

e. Sistem Dua Putaran/Two Round System (TRS).

2. Sistem Representasi Proporsional (PR):

a. Daftar Representasi Proporsional/List Proportional Representation (List PR); serta

b. Suara Tunggal Bisa Dialihkan/Single Transferable Vote (STV).

3. Sistem Campuran:

a. Anggota Proporsional Campuran/Mixed Member Proportional (MMP); serta

b. Sistem Paralel/Parallel System (PS).

4. Sistem-Sistem Lain:

a. Suara Tunggal Tidak Bisa Dialihkan/Single Non-Transferable Vote (SNTV);

b. Suara Terbatas/Limited Vote (LV); serta

c. Penghitungan Borda/Borda Count (BC).

Adapun metode konversi perolehan suara menjadi kursi perwakilan, antara lain yaitu:

1. Metode Divisor/Rata-Rata Tertinggi (Highest Average)

a. D’hondt, dengan rumus:

Jumlah Perolehan Suara Partai/Angka Serial (1, 2, 3, 4, 5, dan seterusnya)

\footnotetext{
hlm. 3.

${ }^{24}$ Robert A. Dahl. (1971). Polyarchy: Participation and Opposition. New Haven: Yale University Press.

${ }^{25}$ Khairul Fahmi. (2010). Op. Cit., hlm. 130.

${ }^{26}$ Andrew Reynolds, Ben Reily, \& Andrew Ellis. (2016). Desain Sistem Pemilu: Buku Panduan International IDEA (Terj. oleh Noor Cholis). Jakarta: Perkumpulan untuk Pemilu dan Demokrasi (Perludem), hlm. 39-131.
} 
b. Sainte Lague

1) Murni, dengan rumus:

Jumlah Perolehan Suara Partai/Angka Serial (1, 3, 5, 7, 9, dan seterusnya)

2) Modifikasi, dengan rumus:

Jumlah Perolehan Suara Partai/Angka Serial (1, 4, 3, 5, 7, dan seterusnya)

c. Danish, dengan rumus:

Jumlah Perolehan Suara Partai/Angka Serial (1, 4, 7, 10, 13, dan seterusnya)

2. Metode Kuota/Suara Sisa Terbanyak (Largest Remainder)

a. Hare Quota, dengan rumus:

Jumlah Perolehan Suara Sah/Kuota Kursi

b. Droop Quota, dengan rumus:

(Jumlah Perolehan Suara Sah/(Kuota Kursi + 1)) + 1

c. Imperiali Quota, dengan rumus:

Jumlah Perolehan Suara Sah/(Kuota Kursi + 2)

d. Hagenbach-Bischoff, dengan rumus:

Jumlah Perolehan Suara Sah/(Kuota Kursi + 1)

3. Metode lain-lain

a. Hare-Niemeyer, dengan rumus:

Jumlah Perolehan Suara Partai/Jumlah Perolehan Suara Sah x Kuota Kursi

\section{B. Napak Tilas Parliamentary Threshold}

Parliamentary threshold merupakan mekanisme ambang batas bagi Partai Politik peserta Pemilu untuk diikutkan pada penghitungan perolehan suara sah guna memperebutkan kuota kursi di Dewan Perwakilan Rakyat. ${ }^{27}$ Secara historis, PT mulai diterapkan di Indonesia pada Pemilu Tahun 2009, sebagaimana berdasarkan Pasal 202 ayat (1) Undang-Undang Republik Indonesia Nomor 10 Tahun 2008 tentang Pemilihan Umum Anggota Dewan Perwakilan Rakyat, Dewan Perwakilan Daerah, dan Dewan Perwakilan Rakyat Daerah (selanjutnya disebut UU No. 10 Tahun 2008), mengatur bahwa:

"Partai Politik Peserta Pemilu harus memenuhi ambang batas perolehan suara sekurang-kurangnya 2,5\% (dua koma lima perseratus) dari jumlah suara sah secara nasional untuk diikutkan dalam penentuan perolehan kursi DPR."

Selanjutnya berdasarkan Pasal 203 ayat (2) UU No. 10 Tahun 2008, mengatur bahwa:

"Suara untuk penghitungan perolehan kursi DPR di suatu daerah pemilihan ialah jumlah suara sah seluruh Partai Politik Peserta Pemilu dikurangi jumlah suara sah Partai Politik Peserta Pemilu yang tidak memenuhi ambang batas perolehan suara ...."

${ }^{27}$ Nur'Ayni Itasari. (2013). Penerapan Parliamentary Threshold pada Pemilihan Umum 2009. Al-Daulah: Jurnal Hukum dan Perundangan Islam, Universitas Islam Negeri Sunan Ampel Surabaya, 3(2), hlm. 367. 
Tabel 1. Perolehan Suara Partai Politik Peserta Pemilu DPR RI Tahun 2009

\begin{tabular}{|c|c|c|c|c|c|}
\hline No. & Peserta Pemilu & $\begin{array}{c}\text { Perolehan } \\
\text { Suara }\end{array}$ & $\begin{array}{c}\text { Persentase } \\
\text { Suara }\end{array}$ & $\begin{array}{c}\text { Jumlah } \\
\text { Kursi }\end{array}$ & $\begin{array}{c}\text { Persentase } \\
\text { Kursi }\end{array}$ \\
\hline 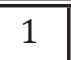 & Partai Demokrat & 21.703 .137 & $20,85 \%$ & 150 & $26,79 \%$ \\
\hline 2 & Partai Golongan Karya & 15.037 .757 & $14,45 \%$ & 107 & $19,11 \%$ \\
\hline 3 & Partai Demokrasi Indonesia Perjuangan & 14.600 .091 & $14,03 \%$ & 95 & $16,96 \%$ \\
\hline 4 & Partai Keadilan Sejahtera & 8.206 .955 & $7,88 \%$ & 57 & $10,18 \%$ \\
\hline 5 & Partai Amanat Nasional & 6.254 .580 & $6,01 \%$ & 43 & $7,68 \%$ \\
\hline 6 & Partai Persatuan Pembangunan & 5.533 .214 & $5,32 \%$ & 37 & $6,61 \%$ \\
\hline 7 & Partai Kebangkitan Bangsa & 5.146 .122 & $4,94 \%$ & 27 & $4,82 \%$ \\
\hline 8 & Partai Gerakan Indonesia Raya & 4.646 .406 & $4,46 \%$ & 26 & $4,64 \%$ \\
\hline 9 & Partai Hati Nurani Rakyat & 3.922 .870 & $3,77 \%$ & 18 & $3,21 \%$ \\
\hline 10 & Partai Bulan Bintang & 1.864 .752 & $1,79 \%$ & 0 & $0,00 \%$ \\
\hline 11 & Partai Damai Sejahtera & 1.541 .592 & $1,48 \%$ & 0 & $0,00 \%$ \\
\hline 12 & Partai Kebangkitan Nasional Ulama & 1.527 .593 & $1,47 \%$ & 0 & $0,00 \%$ \\
\hline 13 & Partai Karya Peduli Bangsa & 1.461 .182 & $1,40 \%$ & 0 & $0,00 \%$ \\
\hline 14 & Partai Bintang Reformasi & 1.264 .333 & $1,21 \%$ & 0 & $0,00 \%$ \\
\hline 15 & Partai Peduli Rakyat Nasional & 1.260 .794 & $1,21 \%$ & 0 & $0,00 \%$ \\
\hline 16 & Partai Keadilan dan Persatuan Indonesia & 934.892 & $0,90 \%$ & 0 & $0,00 \%$ \\
\hline 17 & Partai Demokrasi Pembaruan & 896.660 & $0,86 \%$ & 0 & $0,00 \%$ \\
\hline 18 & Partai Barisan Nasional & 761.086 & $0,73 \%$ & 0 & $0,00 \%$ \\
\hline 19 & Partai Pengusaha dan Pekerja Indonesia & 745.625 & $0,72 \%$ & 0 & $0,00 \%$ \\
\hline 20 & Partai Demokrasi Kebangsaan & 671.244 & $0,64 \%$ & 0 & $0,00 \%$ \\
\hline 21 & Partai Republika Nusantara & 630.780 & $0,61 \%$ & 0 & $0,00 \%$ \\
\hline 22 & Partai Persatuan Daerah & 550.581 & $0,53 \%$ & 0 & $0,00 \%$ \\
\hline 23 & Partai Patriot & 547.351 & $0,53 \%$ & 0 & $0,00 \%$ \\
\hline 24 & Partai Nasional Benteng Kerakyatan Indonesia & 468.696 & $0,45 \%$ & 0 & $0,00 \%$ \\
\hline 25 & Partai Kedaulatan & 437.121 & $0,42 \%$ & 0 & $0,00 \%$ \\
\hline 26 & Partai Matahari Bangsa & 414.750 & $0,40 \%$ & 0 & $0,00 \%$ \\
\hline 27 & Partai Pemuda Indonesia & 414.043 & $0,40 \%$ & 0 & $0,00 \%$ \\
\hline 28 & Partai Karya Perjuangan & 351.440 & $0,34 \%$ & 0 & $0,00 \%$ \\
\hline 29 & Partai Pelopor & 342.914 & $0,33 \%$ & 0 & $0,00 \%$ \\
\hline 30 & Partai Kasih Demokrasi Indonesia & 324.553 & $0,31 \%$ & 0 & $0,00 \%$ \\
\hline 31 & Partai Indonesia Sejahtera & 320.665 & $0,31 \%$ & 0 & $0,00 \%$ \\
\hline 32 & Partai Nasional Indonesia Marhaenisme & 316.752 & $0,30 \%$ & 0 & $0,00 \%$ \\
\hline 33 & Partai Buruh & 265.203 & $0,25 \%$ & 0 & $0,00 \%$ \\
\hline 34 & Partai Perjuangan Indonesia Baru & 197.371 & $0,19 \%$ & 0 & $0,00 \%$ \\
\hline 35 & Partai Persatuan Nahdlatul Ummah Indonesia & 146.779 & $0,14 \%$ & 0 & $0,00 \%$ \\
\hline 36 & Partai Sarikat Indonesia & 140.551 & $0,14 \%$ & 0 & $0,00 \%$ \\
\hline 37 & Partai Penegak Demokrasi Indonesia & 137.727 & $0,13 \%$ & 0 & $0,00 \%$ \\
\hline 38 & Partai Merdeka & 111.623 & $0,11 \%$ & 0 & $0,00 \%$ \\
\hline \multicolumn{2}{|c|}{$\begin{array}{lc}\text { JUMLAH } \\
\end{array}$} & 104.099 .785 & $100,00 \%$ & 560 & $100,00 \%$ \\
\hline
\end{tabular}

Sumber: Komisi Pemilihan Umum Tahun 2009, setelah diolah pada 11 November 2020 
Dari perolehan suara tabel 1 dan berdasarkan Pasal 203 ayat (1) jo. Pasal 203 ayat (2) UU No. 10 Tahun 2008, hanya 9 (sembilan) Partai Politik yang mencapai ambang batas. Adapun 19.048.653 suara sah Partai Politik Peserta Pemilu kemudian dibuang, karena tidak memenuhi ambang batas perolehan suara.

Pemilu Tahun 2014, PT sebagaimana berdasarkan Pasal 208 Undang-Undang Republik Indonesia Nomor 8 Tahun 2012 tentang Pemilihan Umum Anggota Dewan Perwakilan Rakyat, Dewan Perwakilan Daerah, dan Dewan Perwakilan Rakyat Daerah (selanjutnya disebut UU No. 8 Tahun 2012), mengatur bahwa:

"Partai Politik Peserta Pemilu harus memenuhi ambang batas perolehan suara sekurang-kurangnya 3,5\% (tiga koma lima persen) dari jumlah suara sah secara nasional untuk diikutkan dalam penentuan perolehan kursi anggota DPR, DPRD Provinsi, dan DPRD Kabupaten/Kota."

Selanjutnya berdasarkan Pasal 209 ayat (2) UU No. 8 Tahun 2012, mengatur bahwa:

"Suara untukpenghitungan perolehan kursi DPR, DPRD provinsi, dan DPRD Kabupaten/Kota di suatu daerah pemilihan ialah jumlah suara sah seluruh Partai Politik Peserta Pemilu dikurangi jumlah suara sah Partai Politik Peserta Pemilu yang tidak memenuhi ambang batas perolehan suara ...."

Tabel 2. Perolehan Suara Partai Politik Peserta Pemilu DPR RI Tahun 2014

\begin{tabular}{c|l|c|c|c|c}
\hline \hline No. & \multicolumn{1}{|c|}{ Peserta Pemilu } & $\begin{array}{c}\text { Perolehan } \\
\text { Suara }\end{array}$ & $\begin{array}{c}\text { Persentase } \\
\text { Suara }\end{array}$ & $\begin{array}{c}\text { Jumlah } \\
\text { Kursi }\end{array}$ & $\begin{array}{c}\text { Persentase } \\
\text { Kursi }\end{array}$ \\
\hline \hline 1 & Partai Demokrasi Indonesia Perjuangan & 23.681 .471 & $18,95 \%$ & 109 & $19,46 \%$ \\
\hline 2 & Partai Golongan Karya & 18.432 .312 & $14,75 \%$ & 91 & $16,25 \%$ \\
\hline 3 & Partai Gerakan Indonesia Raya & 14.760 .371 & $11,81 \%$ & 73 & $13,04 \%$ \\
\hline 4 & Partai Demokrat & 12.728 .913 & $10,19 \%$ & 61 & $10,89 \%$ \\
\hline 5 & Partai Kebangkitan Bangsa & 11.298 .957 & $9,04 \%$ & 47 & $8,39 \%$ \\
\hline 6 & Partai Amanat Nasional & 9.481 .621 & $7,59 \%$ & 49 & $8,75 \%$ \\
\hline 7 & Partai Keadilan Sejahtera & 8.480 .204 & $6,79 \%$ & 40 & $7,14 \%$ \\
\hline 8 & Partai NasDem & 8.402 .812 & $6,72 \%$ & 35 & $6,25 \%$ \\
\hline 9 & Partai Persatuan Pembangunan & 8.157 .488 & $6,53 \%$ & 39 & $6,96 \%$ \\
\hline 10 & Partai Hati Nurani Rakyat & 6.579 .498 & $5,26 \%$ & 16 & $2,86 \%$ \\
\hline 11 & Partai Bulan Bintang & 1.825 .750 & $1,46 \%$ & 0 & $0,00 \%$ \\
\hline 12 & Partai Keadilan dan Persatuan Indonesia & 1.143 .094 & $0,91 \%$ & 0 & $0,00 \%$ \\
\hline \hline
\end{tabular}

Sumber: Komisi Pemilihan Umum Tahun 2014, setelah diolah pada 11 November 2020

Dari perolehan suara tabel di atas dan berdasarkan Pasal 203 jo. Pasal 209 ayat (2) UU No. 8 Tahun 2012, terdapat 10 Partai Politik yang mencapai ambang batas. Adapun 2.968.844 suara sah Partai Politik Peserta Pemilu kemudian dibuang, karena tidak memenuhi ambang batas perolehan suara.

Pemilu Tahun 2019, PT sebagaimana berdasarkan Pasal 414 ayat (1) UU No. 7 Tahun 2017, mengatur bahwa: 
"Partai Politik Peserta Pemilu harus memenuhi ambang batas perolehan suara paling sedikit 4\% (empat persen) dari jumlah suara sah secara nasional untuk diikutkan dalam penentuan perolehan kursi anggota DPR."

Selanjutnya berdasarkan Pasal 415 ayat (1) UU No. 7 Tahun 2017, mengatur bahwa:

"Partai Politik Peserta Pemilu yang tidak memenuhi ambang batas perolehan suara ... tidak disertakan pada penghitungan perolehan kursi DPR di setiap daerah pemilihan."

Tabel 3. Perolehan Suara Partai Politik Peserta Pemilu DPR RI Tahun 2019

\begin{tabular}{c|l|c|c|c|c}
\hline \hline No. & \multicolumn{1}{|c|}{ Peserta Pemilu } & $\begin{array}{c}\text { Perolehan } \\
\text { Suara }\end{array}$ & $\begin{array}{c}\text { Persentase } \\
\text { Suara }\end{array}$ & $\begin{array}{c}\text { Jumlah } \\
\text { Kursi }\end{array}$ & $\begin{array}{c}\text { Persentase } \\
\text { Kursi }\end{array}$ \\
\hline \hline 1 & Partai Demokrasi Indonesia Perjuangan & 27.503 .961 & $19,47 \%$ & 128 & $22,26 \%$ \\
\hline 2 & Partai Gerakan Indonesia Raya & 17.596 .839 & $12,45 \%$ & 78 & $13,57 \%$ \\
\hline 3 & Partai Golongan Karya & 17.229 .789 & $12,19 \%$ & 85 & $14,79 \%$ \\
\hline 4 & Partai Kebangkitan Bangsa & 13.570 .970 & $9,61 \%$ & 58 & $10,09 \%$ \\
\hline 5 & Partai Nasional Demokrat & 12.661 .792 & $8,96 \%$ & 59 & $10,26 \%$ \\
\hline 6 & Partai Keadilan Sejahtera & 11.493 .663 & $8,13 \%$ & 50 & $8,70 \%$ \\
\hline 7 & Partai Demokrat & 10.876 .057 & $7,70 \%$ & 54 & $9,39 \%$ \\
\hline 8 & Partai Amanat Nasional & 9.572 .623 & $6,78 \%$ & 44 & $7,69 \%$ \\
\hline 9 & Partai Persatuan Pembangunan & 6.323 .147 & $4,48 \%$ & 19 & $3,30 \%$ \\
\hline 10 & Partai Persatuan Indonesia & 3.738 .320 & $2,65 \%$ & 0 & $0,00 \%$ \\
\hline 11 & Partai Berkarya & 2.902 .495 & $2,05 \%$ & 0 & $0,00 \%$ \\
\hline 12 & Partai Solidaritas Indonesia & 2.650 .361 & $1,87 \%$ & 0 & $0,00 \%$ \\
\hline 13 & Partai Hati Nurani Rakyat & 2.161 .507 & $1,53 \%$ & 0 & $0,00 \%$ \\
\hline 14 & Partai Bulan Bintang & 1.990 .848 & $1,41 \%$ & 0 & $0,00 \%$ \\
\hline 15 & Partai Gerakan Perubahan Indonesia & 702.536 & $0,50 \%$ & 0 & $0,00 \%$ \\
\hline 16 & Partai Keadilan dan Persatuan Indonesia & 312.775 & $0,22 \%$ & 0 & $0,00 \%$ \\
\hline \hline & & $\mathbf{1 4 1 . 2 8 7 . 6 8 3}$ & $\mathbf{1 0 0 , 0 0 \%}$ & $\mathbf{5 7 5}$ & $\mathbf{1 0 0 , 0 0 \%}$ \\
\hline \hline
\end{tabular}

Sumber: Komisi Pemilihan Umum Tahun 2019, setelah diolah pada 11 November 2020

Dari perolehan suara tabel di atas dan berdasarkan Pasal 414 ayat (1) jo. Pasal 415 ayat (1) UU No. 7 Tahun 2017, hanya 9 (sembilan) Partai Politik yang mencapai ambang batas. Adapun 14.458.842 suara sah Partai Politik Peserta Pemilu kemudian dibuang, karena tidak memenuhi ambang batas perolehan suara.

\section{Pemilihan Sistem Pemilu}

Pilihan atas sistem Pemilu merupakan salah satu keputusan kelembagaan paling penting bagi negara demokrasi di manapun. Pilihan sistem Pemilu pada dasarnya lebih merupakan sebuah proses politik dan pertimbangan keunggulan politis hampir selalu menjadi faktor dalam pilihan sistem Pemilu. Referendum Italia tahun 1993 menyebabkan perubahan ke sistem Mixed Member Proportional (MMP) 
untuk pemilihan umum tahun berikutnya. ${ }^{28}$ Kondisi tersebut juga menandai awal serangkaian perubahan signifikan dalam sistem-sistem Pemilu di seluruh dunia.

Kebanyakan negara yang mengubah sistem Pemilunya, cenderung ke arah yang lebih condong pada proporsionalitas, baik dengan menambahkan sebuah unsur PR ke dalam sistem pluralitas (menjadi sistem Paralel atau MMP) atau sepenuhnya mengganti sistem mereka dengan sistem List $P R$. Perubahan yang paling lazim adalah dari sistem Pluralitas/Mayoritas/Distrik menjadi sistem Campuran, dan tak ada satu contoh pun dari arah sebaliknya. Adapun untuk Madagaskar, yang pindah dari sebuah sistem List $P R$, bukan menjadi sistem Pluralitas/Mayoritas/ Distrik murni, tetapi menjadi hibrida di mana porsi sistem FPTP lebih besar dari sistem list $P R^{29}$

Sistem Pemilu mengonversi perolehan suara dalam pemilihan umum menjadi kursi-kursi yang dimenangkan oleh partai dan kandidat. Merancang sebuah sistem Pemilu dimulai dengan sebuah daftar kriteria yang merangkum apa yang ingin dicapai, apa yang ingin dihindari dam dalam arti luas, seperti apa badan legislatif dan pemerintah eksekutif yang ingin dilihat. Ada beberapa cara bagaimana sistem Pemilu dilahirkan, antara lain yaitu: ${ }^{30}$

1. Diwariskan dari pemerintahan kolonial atau pendudukan, tanpa melakukan suatu perubahan. Contoh: Kepulauan Solomon, Malawi, Mali, dan Palau;

2. Negosiasi antara kelompok-kelompok komunal yang bertujuan untuk mengakhiri peperangan dan menciptakan perdamaian. Contoh: Afrika Selatan, Lebanon, dan Lesotho;

3. Keterlibatan kelompok-kelompok atau pihak-pihak tertentu dalam merekonstruksi perpolitikan di wilayah pasca konflik. Contoh: Dewan Nasional Transisional dan Otoritas Koalisi Irak di Afghanistan;

4. Perencanaan dan keterlibatan dari rezim otoriter guna memastikan kekuasaannya dapat bertahan pada sistem Pemilu yang baru. Contoh: Chili;

5. Pembentukan komisi ahli dalam mengkaji sistem Pemilu (Inggris atau Mauritius), dimana menghadirkan suatu rekomendasi yang dibawa ke referendum nasional (Selandia Baru), hingga rekomendasi yang lebih spesifik membahas tentang pemungutan suara legislatif berdasarkan konteks konstitusional yang lebih luas (Fiji);

6. Pembentukan majelis warga negara non-ahli sebagai bentuk pelibatan warga negara yang lebih luas, guna menghadirkan suatu rekomendasi yang dibawa ke referendum nasional hingga pada tingkat Provinsi. Contoh: British Columbia.

Pada Tahun 2019, Pemilu di Indonesia diselenggarakan secara serentak antara Pemilu Eksekutif (Presiden dan Wakil Presiden) dengan Pemilu Legislatif (DPR,

${ }^{28}$ Refly Harun. (2009). Memilih Sistem Pemilu dalam Periode Transisi. Jurnal Konstitusi, Mahkamah Konstitusi RI, 2(1), hlm. 104.

${ }^{29}$ Andrew Reynolds, Ben Reily, \& Andrew Ellis. (2016). Op. Cit., hlm. 27.

${ }^{30}$ Ibid., hlm. 17-18. 
DPD, dan DPRD tingkat Provinsi dan Kabupaten/Kota). Adapun pada Pemilu Legislatif, terdapat 27 Partai Politik yang mendaftar di Komisi Pemilihan Umum (KPU) dan hanya 16 Partai Politik yang dinyatakan lolos sebagai Partai Politik peserta Pemilu.

Komisi Pemilihan Umum (KPU) telah menetapkan perolehan suara Partai Politik hasil Pemilu 2019, sebagaimana yang telah diuraikan pada tabel sebelumnya. Terdapat 139.971 .260 (100\%) suara sah keseluruhan Partai Politik Peserta Pemilu, dimana 9 (sembilan) Partai Politik yang mencapai PT dengan perolehan sebesar 126.376 .418 (90,29\%). Adapun 13.594 .842 (9,71\%) suara sah Partai Politik Peserta Pemilu kemudian dibuang, karena tidak memenuhi ambang batas perolehan suara. Kondisi ini menunjukkan bahwa belum semua suara pemilih terwakili di parlemen.

Wacana tentang sistem Pemilu dan keberadaan PT, belakangan ini menjadi pembahasan dalam RUU Pemilu sebagai landasan hukum Pemilu Tahun 2024. Penyederhanaan jumlah Partai Politik menjadi satu di antara beberapa pembahasan dalam RUU tersebut.

Adapun serangkaian dari persoalan sistem Pemilu, penerapan mandat representasi yang partisan harus menjadi tolok ukur dalam perolehan kursi bagi Partai Politik. Hal ini dapat dinilai berdasarkan jumlah penyebaran warga yang tidak sama antara daerah satu dan lainnya. Berdasarkan pemikiran ini, sistem Representasi Proporsional menjadi sistem Campuran sebagai alternatif yang patut dipertimbangkan. Lebih lanjut, terkait perolehan dan perhitungan suara yang dimana hingga saat ini masih terdapat kelemahannya, dibutuhkan formulasi khusus dimana Partai Politik Peserta Pemilu yang dinyatakan tidak memenuhi ambang batas dapat menempuh jalur koalisi untuk mencapai ambang batas, bahkan sampai pada pilihan untuk meniadakan PT (ambang batas perolehan suara 0\%).

Hal tersebut dilakukan guna memastikan seluruh suara pemilih (100\%) harus terwakili di parlemen. Selanjutnya, koalisi Partai dimaksud sebagai pembuktian, bahwa:

1. Indonesia sebagai negara penganut teori kedaulatan rakyat, berdasarkan Pasal 1 ayat (2) Undang-Undang Dasar Negara Republik Indonesia Tahun 1945 (selanjutnya disebut UUD NRI Tahun 1945), yang mengatur bahwa "Kedaulatan berada di tangan rakyat dan dilaksanakan menurut Undang-Undang Dasar", perwujudan sila ke-5 Pancasila bahwa "Kerakyatan yang dipimpin oleh hikmah kebijaksanaan dalam permusyawaratan perwakilan" dan melaksanakan Pembukaan UUD 1945, bahwa:

"Kemudian daripada itu untuk membentuk suatu Pemerintah Negara Indonesia ... dalam suatu Undang-Undang Dasar Negara Indonesia, yang terbentuk dalam suatu susunan Negara Republik Indonesia yang berkedaulatan rakyat... ." 
2. Sarana komunikasi politik dalam menjembatani pemerintah dan masyarakat, menyatukan orang-orang yang mempunyai ideologi serupa sehingga pikiran dan orientasi mereka bisa dikonsolidasikan, merumuskan kepentingan bersama mengenai usul kebijakan yang diperjuangkan melalui parlemen untuk menjadi kebijakan umum.

\section{KESIMPULAN DAN SARAN}

Berdasarkan uraian hasil dan pembahasan, maka dapat ditarik kesimpulan bahwa pemberlakuan parliamentary threshold dalam sistem Pemilu di Indonesia bertentangan dengan konsep kedaulatan rakyat. Adapun penerapan sistem khususnya pada Pemilu 2024, patut mempertimbangkan sistem Campuran sebagai alternatif dari sistem Representasi Proporsional yang selama ini diterapkan pada Pemilu di Indonesia. Selanjutnya, dibutuhkan formulasi khusus dimana Partai Politik Peserta Pemilu yang dinyatakan tidak memenuhi ambang batas dapat menempuh jalur koalisi untuk mencapai ambang batas, bahkan sampai pada pilihan untuk meniadakan parliamentary threshold (ambang batas perolehan suara 0\%). Hal ini akan menjadi jalan tengah atas kebutuhan pencapaian proporsionalitas sistem Pemilu, sebagai bentuk akomodasi suara pemilih serta kepastian hukum atas kedaulatan rakyat, serta kebutuhan menciptakan sistem Presidensialisme yang semakin efektif di masa yang akan datang.

\section{REFERENSI}

Abd. Rahman Mawazi. (2017). Dinamika Partai Politik dalam Sistem Presidensil di Indonesia. In Right: Jurnal Agama dan Hak Azazi Manusia, Universitas Islam Negeri Sunan Kalijaga Yogyakarta, 6(2), hlm. 137-155.

Abdul Rokhim. (2011). Pemilihan Umum dengan Model "Parliamentary Threshold" Menuju Pemerintahan yang Demokratis di Indonesia. DIH: Jurnal Ilmu Hukum, Universitas 17 Agustus 1945 Surabaya, 7(14), hlm. 85-94. doi: https://doi. org/10.30996/dih.v7i14.266

Agus Riwanto. (2014). Inkompatibilitas Asas Pengaturan Sistem Pemilu dengan Sistem Pemerintahan Presidensial di Indonesia. Jurnal Hukum Ius Quia Iustum, Universitas Islam Indonesia Yogyakarta, 21(4), hlm. 509-530. doi: https://doi. org/10.20885/iustum.vol21.iss4.art1

Andrew Reynolds, Ben Reily, \& Andrew Ellis. (2016). Desain Sistem Pemilu: Buku Panduan International IDEA (Terj. oleh Noor Cholis). Jakarta: Perkumpulan untuk Pemilu dan Demokrasi (Perludem).

David Held. (1987). Models of Democracy. Cambridge: Polity Press.

Dhani Kurniawan. (2016). Demokrasi Indonesia dalam Lintasan Sejarah yang Nyata dan yang Seharusnya. Mozaik, Universitas Negeri Yogyakarta, 8(1), hlm. 94-111. doi: https://doi.org/10.21831/moz.v8i1.10770

Ellya Rosana. (2012). Partai Politik dan Pembangunan Politik. Jurnal Tapis: Jurnal Teropong Aspirasi Politik Islam, Universitas Islam Negeri Raden Intan Lampung, 8(1), hlm. 135-150. 
H. Hastangka, Armaidy Armawi, \& Kaelan Kaelan. (2018). Analisis Putusan Mahkamah Konstitusi Nomor 100/PUU-XI/2013 tentang Pembatalan Frasa 4 Pilar Kehidupan Berbangsa dan Bernegara. Mimbar Hukum, Universitas Gadjah Mada, 30(2), hlm. 230-245. doi: https://doi.org/10.22146/jmh.32660

Irvan Mawardi. (2014). Dinamika Sengketa Hukum Administrasi di Pemilukada: Mewujudkan Electoral Justice dalam Kerangka Negara Hukum Demokratis. Yogyakarta: Rangkang Education.

Jerry Indrawan \& M. Prakoso Aji. (2019). Penyederhanaan Partai Politik Melalui Parliamentary Threshold: Pelanggaran Sistematis terhadap Kedaulatan Rakyat. Jurnal Penelitian Politik, Pusat Penelitian Politik, Lembaga Ilmu Pengetahuan Indonesia (LIPI), 16(2), hlm. 155-166.

Jorge J. E. Gracia. (1990). Texts and Their Interpretation. The Review of Metaphysics, Philosophy of Education Society, Inc., 43(3), hlm. 495-542.

Joseph A. Schumpeter. (1947). Capitalism, Socialism, and Democracy. New York: Harper \& Brothers.

Khairul Fahmi. (2010). Prinsip Kedaulatan Rakyat dalam Penentuan Sistem Pemilihan Umum Anggota Legislatif. Jurnal Konstitusi, Mahkamah Konstitusi RI, 7(3), hlm. 119-160.

Latipah Nasution. (2017). Pemilu dan Kedaulatan Rakyat. 'Adalah: Jurnal Ilmu Hukum, Universitas Islam Negeri Syarif Hidayatullah Jakarta, 1(9), hlm. 83-84.

Luthfi Widagdo Eddyono. (2017). Wacana Desentralisasi Partai Politik: Kajian Original Intent dan Pemaknaan Sistematik UUD 1945. Jurnal Konstitusi, Mahkamah Konstitusi RI, 14(1), hlm. 82-103. doi: https://doi.org/10.31078/jk1414

Mohamad Faisal Ridho. (2017). Kedaulatan Rakyat sebagai Perwujudan Demokrasi Indonesia. 'Adalah:Jurnal Ilmu Hukum, Universitas Islam Negeri SyarifHidayatullah Jakarta, 8(1), hlm. 79-80.

Nur'Ayni Itasari. (2013). Penerapan Parliamentary Threshold pada Pemilihan Umum 2009. Al-Daulah: Jurnal Hukum dan Perundangan Islam, Universitas Islam Negeri Sunan Ampel Surabaya, 3(2), hlm. 356-374. doi: https://doi.org/10.15642/ ad.2013.3.2.356-374

Nurul Qamar \& Farah Syah Rezah. (2020). Metode Penelitian Hukum: Doktrinal dan Non-Doktrinal. Makassar: CV. Social Politic Genius (SIGn).

Peraturan Pemerintah Republik Indonesia Nomor 1 Tahun 1970 tentang Pelaksanaan Undang-Undang Nomor 15 Tahun 1969 tentang Pemilihan Umum AnggotaAnggota Badan Permusyawaratan/Perwakilan Rakyat. (Lembaran Negara Republik Indonesia Tahun 1970 Nomor 2. Tambahan Lembaran Negara Republik Indonesia Nomor 2919).

Peraturan Pemerintah Republik Indonesia Nomor 1 Tahun 1976 tentang Pelaksanaan Undang-Undang Nomor 15 Tahun 1969 tentang Pemilihan Umum AnggotaAnggota Badan Permusyawaratan/Perwakilan Rakyat Sebagaimana Diubah dengan Undang-Undang Nomor 4 Tahun 1975. (Lembaran Negara Republik Indonesia Tahun 1976 Nomor 1. Tambahan Lembaran Negara Republik Indonesia Nomor 3065). 
Peraturan Pemerintah Republik Indonesia Nomor 41 Tahun 1980 tentang Pelaksanaan Undang-Undang Pemilihan Umum. (Lembaran Negara Republik Indonesia Tahun 1980 Nomor 67. Tambahan Lembaran Negara Republik Indonesia Nomor 3181).

Peraturan Pemerintah Republik Indonesia Nomor 35 Tahun 1985 tentang Pelaksanaan Undang-Undang Nomor 15 Tahun 1969 tentang Pemilihan Umum AnggotaAnggota Badan Permusyawaratan/Perwakilan Rakyat Sebagaimana Telah Tiga Kali Diubah Terakhir dengan Undang-Undang Nomor 1 Tahun 1985. (Lembaran Negara Republik Indonesia Tahun 1985 Nomor 50. Tambahan Lembaran Negara Republik Indonesia Nomor 3301).

Peraturan Pemerintah Republik Indonesia Nomor 43 Tahun 1985 tentang Perubahan Peraturan Pemerintah Nomor 35 Tahun 1985 tentang Pelaksanaan UndangUndang Nomor 15 Tahun 1969 tentang Pemilihan Umum Anggota-Anggota Badan Permusyawaratan/Perwakilan Rakyat Sebagaimana Telah Tiga Kali Diubah Terakhir dengan Undang-Undang Nomor 1 Tahun 1985. (Lembaran Negara Republik Indonesia Tahun 1985 Nomor 64. Tambahan Lembaran Negara Republik Indonesia Nomor 3310).

Peraturan Pemerintah Republik Indonesia Nomor 37 Tahun 1990 tentang Perubahan Atas Peraturan Pemerintah Nomor 35 Tahun 1985 tentang Pelaksanaan UndangUndang Nomor 15 Tahun 1969 tentang Pemilihan Umum Anggota-Anggota Badan Permusyawaratan/Perwakilan Rakyat Sebagaimana Telah Beberapa Kali Diubah. (Lembaran Negara Republik Indonesia Tahun 1990 Nomor 47. Tambahan Lembaran Negara Republik Indonesia Nomor 3417).

Peraturan Pemerintah Republik Indonesia Nomor 10 Tahun 1995 tentang Perubahan Atas Peraturan Pemerintah Nomor 35 Tahun 1985 tentang Pelaksanaan Undang-Undang Pemilihan Umum Sebagaimana Telah Diubah dengan Peraturan Pemerintah Nomor 43 Tahun 1985 dan Peraturan Pemerintah Nomor 37 Tahun 1990. (Lembaran Negara Republik Indonesia Tahun 1995 Nomor 22. Tambahan Lembaran Negara Republik Indonesia Nomor 3594).

Peraturan Pemerintah Republik Indonesia Nomor 74 Tahun 1996 tentang Perubahan Atas Peraturan Pemerintah Nomor 35 Tahun 1985 tentang Pelaksanaan UndangUndang Pemilihan Umum Sebagaimana Telah Beberapa Kali Diubah, Terakhir dengan Peraturan Pemerintah Nomor 10 Tahun 1995. (Lembaran Negara Republik Indonesia Tahun 1996 Nomor 113. Tambahan Lembaran Negara Republik Indonesia Nomor 3665).

Ramlan Surbakti, Didik Supriyanto, \& Topo Santoso. (2011). Memaksimalkan Derajat Keterwakilan Partai Politik dan Meningkatkan Akuntabilitas Calon Terpilih. Jakarta: Kemitraan bagi Pembaruan Tata Pemerintahan.

Refly Harun. (2009). Memilih Sistem Pemilu dalam Periode Transisi. Jurnal Konstitusi, Mahkamah Konstitusi RI, 2(1), hlm. 97-106.

Robert A. Dahl. (1971). Polyarchy: Participation and Opposition. New Haven: Yale University Press.

S. Sodikin. (2014). Kedaulatan Rakyat dan Pemilihan Kepala Daerah dalam Konteks Undang-Undang Dasar Negara Republik Indonesia Tahun 1945. Jurnal Cita Hukum, Universitas Islam Negeri Syarif Hidayatullah Jakarta, 2(1), hlm. 103-116. doi: https://doi.org/10.15408/jch.v1i1.1453 
Setyo Nugroho. (2013). Demokrasi dan Tata Pemerintahan dalam Konsep Desa dan Kelurahan. Jurnal Cita Hukum, Universitas Islam Negeri Syarif Hidayatullah Jakarta, 1(2), hlm. 247-262. doi: http://dx.doi.org/10.15408/jch.v1i2.2633

Sri Hastuti Puspitasari. (2004). Pemilu dan Demokrasi Telaah terhadap Prasyarat Normatif Pemilu. Jurnal Hukum Ius Quia Iustum, Universitas Islam Indonesia Yogyakarta, 11(25), hlm. 135-148. doi: https://doi.org/10.20885/iustum.vol11. iss25.art11

Sunny Ummul Firdaus. (2011). Relevansi Parliamentary Threshold terhadap Pelaksanaan Pemilu yang Demokratis. Jurnal Konstitusi, Mahkamah Konstitusi RI, 8(2), hlm. 93-112.

Syofyan Hadi. (2013). Fungsi Representative Dewan Perwakilan Rakyat Daerah dalam Sistem Otonomi. DIH: Jurnal Ilmu Hukum, Universitas 17 Agustus 1945 Surabaya, 9(17), hlm. 47-53. doi: https://doi.org/10.30996/dih.v9i17.249

Undang-Undang Dasar Negara Republik Indonesia Tahun 1945.

Undang-Undang Republik Indonesia Nomor 7 Tahun 1953 tentang Pemilihan Anggota Konstituante dan Anggota Dewan Perwakilan. (Lembaran Negara Republik Indonesia Tahun 1953 Nomor 29).

Undang-Undang Republik Indonesia Nomor 15 Tahun 1969 tentang Pemilihan Umum Anggota-Anggota Badan Permusyawaratan/Perwakilan Rakyat. (Lembaran Negara Republik Indonesia Tahun 1969 Nomor 58. Tambahan Lembaran Negara Republik Indonesia Nomor 2914).

Undang-Undang Republik Indonesia Nomor 4 Tahun 1975 tentang Perubahan UndangUndang Nomor 15 Tahun 1969 tentang Pemilihan Umum Anggota-Anggota Badan Permusyawaratan/Perwakilan Rakyat. (Lembaran Negara Republik Indonesia Tahun 1975 Nomor 38. Tambahan Lembaran Negara Republik Indonesia Nomor 3063).

Undang-Undang Republik Indonesia Nomor 2 Tahun 1980 tentang Perubahan Atas Undang-Undang Nomor 15 Tahun 1969 tentang Pemilihan Umum AnggotaAnggota Badan Permusyawaratan/Perwakilan Rakyat Sebagaimana Telah Diubah dengan Undang-Undang Nomor 4 Tahun 1975. (Lembaran Negara Republik Indonesia Tahun 1980 Nomor 24. Tambahan Lembaran Negara Republik Indonesia Nomor 3163).

Undang-Undang Republik Indonesia Nomor 1 Tahun 1985 tentang Perubahan Atas Undang-Undang Nomor 15 Tahun 1969 tentang Pemilihan Umum AnggotaAnggota Badan Permusyawaratan/Perwakilan Rakyat Sebagaimana Telah Diubah dengan Undang-Undang Nomor 2 Tahun 1980. (Lembaran Negara Republik Indonesia Tahun 1985 Nomor 1. Tambahan Lembaran Negara Republik Indonesia Nomor 3281).

Undang-Undang Republik Indonesia Nomor 3 Tahun 1999 tentang Pemilihan Umum. (Lembaran Negara Republik Indonesia Tahun 1999 Nomor 23. Tambahan Lembaran Negara Republik Indonesia Nomor 3810). 
Undang-Undang Republik Indonesia Nomor 12 Tahun 2003 tentang Pemilihan Umum Anggota Dewan Perwakilan Rakyat, Dewan Perwakilan Daerah, dan Dewan Perwakilan Rakyat Daerah. (Lembaran Negara Republik Indonesia Tahun 2003 Nomor 37. Tambahan Lembaran Negara Republik Indonesia Nomor 4277).

Undang-Undang Republik Indonesia Nomor 10 Tahun 2008 tentang Pemilihan Umum Anggota Dewan Perwakilan Rakyat, Dewan Perwakilan Daerah, dan Dewan Perwakilan Rakyat Daerah. (Lembaran Negara Republik Indonesia Tahun 2008 Nomor 51. Tambahan Lembaran Negara Republik Indonesia Nomor 4836).

Undang-Undang Republik Indonesia Nomor 8 Tahun 2012 tentang Pemilihan Umum Anggota Dewan Perwakilan Rakyat, Dewan Perwakilan Daerah, dan Dewan Perwakilan Rakyat Daerah. (Lembaran Negara Republik Indonesia Tahun 2012 Nomor 117. Tambahan Lembaran Negara Republik Indonesia Nomor 5316).

Undang-Undang Republik Indonesia Nomor 7 Tahun 2017 tentang Pemilihan Umum. (Lembaran Negara Republik Indonesia Tahun 2017 Nomor 182. Tambahan Lembaran Negara Republik Indonesia Nomor 6109).

I Fahri Bachmid. (2020). Eksistensi Kedaulatan Rakyat dan Implementasi Parliamentary I Threshold dalam Sistem Pemilihan Umum di Indonesia. SIGn Jurnal Hukum, CV. Social I Politic Genius (SIGn), 2(2), hlm. 87-103. doi: https://doi.org/10.37276/sjh.v2i2.83

ᄂ _ _ _ _ _ _ _ _ _ _ _ _ _ _ _ _ _ _ _ _ _ - _ _ _ _ _ _ _ _ _ . 